\title{
Lichenized fungi Stereocaulon foliolosum Nyl. (Stereocaulaceae, Ascomycota), indicator of ambient air metal deposition in a temperate habitat of Kumaun, central Himalaya, India
}

\author{
Pramod Nag ${ }^{1,2}$, Rajan K. Gupta ${ }^{1 * *}$ and Dalip Kumar Upreti ${ }^{2}$ \\ ${ }^{1}$ Department of Botany, Pt. L.M.S. Government Post Graduate College, \\ Rishikesh (Dehradun)-249201, Uttarakhand, India \\ ${ }^{2}$ Lichenology Laboratory, Plant Diversity, Systematics and Herbarium Division, CSIR-National Botanical \\ Research Institute, Lucknow-226001, Uttar Pradesh, India \\ ${ }^{\#}$ Current affiliation: Centre of advanced study in Botany, Institute of Science, Banaras Hindu University, \\ Varanasi-221005, Uttar Pradesh, India
}

*Corresponding Author: rajankgupta1@ rediffmail.com

[Accepted: 22 July 2019]

\begin{abstract}
Himalayan habitats in the past three decades have undergone a tremendous change in the land use pattern. The increase in urbanization and associated vehicular movement had increased the heavy metal influx in the ambient air of Himalayan ecosystems. Bioindicators such as lichens due to their slow growth, longer lifespan and maximum absorption of nutrients through atmospheric deposition, can be used as an appropriate indicator of long-term heavy metal deposition in the Himalaya. In the current study, a terricolous lichen Stereocaulon foliolosum was studied in the temperate habitat of Munsyari, Pithoragarh district, Uttarakhand, central Himalaya, for its ability as a bioindicator of ambient air heavy metal deposition along with land use linked vehicular exhaust gradient. In the current study, Stereocaulon foliolosum was analyzed for lichen diversity and seven heavy metals- $(\mathrm{Mg}, \mathrm{Zn}, \mathrm{Cu}, \mathrm{Pb}, \mathrm{Mn}, \mathrm{Ni}, \mathrm{Cd}$ ) deposition in five plots in Khaliya bugyal-Munsyari landscape along gradients of land use and elevation. The maximum heavy metal deposition was recorded in plots along roads which minimized in Khaliya bugyal. The total heavy metal load $\left(\Sigma \mathrm{M}_{7}\right)$ was found indicative of land use gradient followed by $\mathrm{Mg}, \mathrm{Zn}, \mathrm{Cu}$ and $\mathrm{Ni}$ accumulation in lichen thallus. The study concluded that the diversity of Stereocaulon foliolosum was negatively correlated to the vehicular density which was maximum at moderate elevations exhibiting intense land use and maximum vehicular movement. The study thus established that change in lichen diversity can be an appropriate indicator of land use linked pollution gradients in temperate habitat in Kumaun, central Himalaya.
\end{abstract}

Keywords: Diversity - Heavy metal - Terricolous lichen - Vehicular density.

[Cite as: Nag P, Gupta RK \& Upreti DK (2019) Lichenized fungi Stereocaulon foliolosum Nyl. (Stereocaulaceae, Ascomycota), indicator of ambient air metal deposition in a temperate habitat of Kumaun, central Himalaya, India. Tropical Plant Research 6(2): 199-205]

\section{INTRODUCTION}

The Lichens, a self-supporting mutualistic association of one or two (Spribille et al. 2016) fungus and a green and/or blue-green algae, are by far known as one of the most successful symbiosis in nature (Honegger 1991, Galloway 1992). The peculiar morpho-anatomy of lichen thallus, characterized by the absence of root and cuticle, slow growth, long-life, the large-scale absorbance of the nutrients directly from the atmosphere makes them highly sensitive to environmental changes and allow them to accumulate pollutants in their tissue (Purvis 2000). The variation in diversity of lichen species has been an important marker of the pollution gradient in various habitats (Loppi et al. 2004, Pinho et al. 2012, Giordani et al. 2012).

Himalayan habitats in the recent past have undergone a drastic change in the land use pattern, due to the population growth and related zoo-anthropogenic activities (Rao \& Pant 2001, Tiwari 2008). The Kumaun Himalaya along with western Nepal constitutes the central Himalayan botanical region (Singh \& Singh 1987). 
The topography of Kumaun Himalaya is mountainous with gentle slopes and vegetation mainly dominated by species of Quercus (Oak-Banj). Lichens, in the Himalaya, have been reported as bioindicators, of all sought of natural, as well as zoo-anthropogenic perturbations ranging from habitat heterogeneity, grazing, trampling to air pollution (Bergamaschi et al. 2002, Rai et al. 2012a, b, Kumar et al. 2014, Gupta et al. 2016, 2017, 2018, Yadav et al. 2018).

In this study, we sampled a common terricolous lichen Stereocaulon foliolosum Nyl. from a temperate habitat of Kumaun Himalaya and assess the bioindicator capability of the lichen for land use coupled pollution gradients along an elevation gradient.

\section{MATERIALS \& METHODS}

\section{Study area}

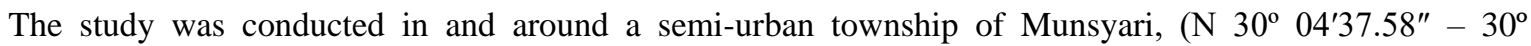

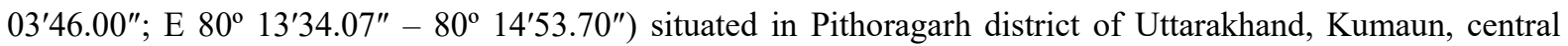
Himalaya. The area included the Khaliya bugyal (a state government notified medicinal plant conservation areaMPCA) and the Munsyari town. The township exhibits various land use ranging from natural conserved managed forests to roadside scrublands and agricultural land. The climate of the region is temperate with temperature ranging from $25^{\circ} \mathrm{C}$ to $-12^{\circ} \mathrm{C}$. Precipitation occurs in the form of rain, soot or snowfall. Maximum precipitation occurs through the south-west monsoon in months of July-August. Snowfall occurs in the months of Feb-March. The vegetation of the region can be classified as Quercus-Rhododendron mixed forests with isolated stands of Abies spp. in the higher elevation of conserved forests.

The local population of Munsyari is mainly involved in agriculture, animal husbandry and occasional collection of rare Himalayan medicinal herbs. The township is also a tourist hub which acts as the base camp for alpine glacier treks to Mila, Ralam, and Namik. The tourism and other activities in the area involve the movement of automobiles which along with domestic and commercial exhaust contribute to pollutants (heavy metals and polycyclic aromatic hydrocarbons) in ambient air.

The climate, topography and habitat heterogeneity of the region make it suitable for the flourishing of lichen communities having diverse substrate, growth-form, and photobiont preferences. Stereocaulon foliolosum due to its morphological tolerance to harsher climatic conditions, grazing/ footfall induced trampling and biochemical defense against herbivore grow vigorously on the ground or on soil accumulated on rocky outcrops in Himalaya (Rai et al. 2012a, b). The study was conducted on samples of Stereocaulon foliolosum, collected from five plots situated in Khaliya bugyal (on the outskirts of Munsyari) and in the township of Munsyari (Fig. 1).

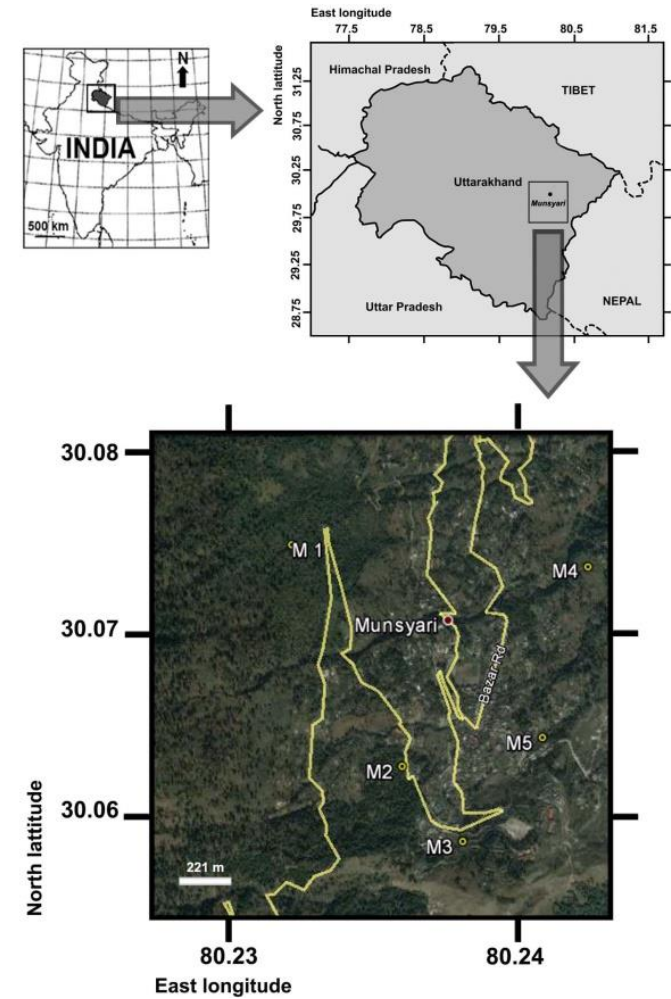

Figure 1. Location map of the study site and plot laid in the Khaliya bugyal-Munsyari landscape of Pithoragarh district, Uttarakhand, central Himalaya (Prepared using Google Earth 2018, processed in SURFER version 11.0.62). 
Field methods and data recording

The sampling of Stereocaulon foliolosum was done employing a two-way random stratified sampling method where the land use was the primary stratifying variable along the elevation gradient of the study area (Greig-Smith 1983, Krebs 1989, Holt et al. 2007, Rai et al. 2012b) (Table 1). In order to maximize the sampling efficiency and clipping related difficulties a mixed quadrat sampling approach was undertaken (KakaÏ et al. 2008). Five circular plots ( $24 \mathrm{~m}$ in diam.) were randomly selected in the study landscape and lichen diversity was recorded using a standardized probabilistic method with three $10 \times 50 \mathrm{~cm}$ narrow frequency grids subdivided into five sampling units of $10 \times 10 \mathrm{~cm}$, laid randomly i.e. fifteen, $10 \times 10 \mathrm{~cm}$ sampling units were laid in each plot (Scheidegger et al. 2002, Rai et al. 2012b, Gasparyan et al. 2018). Four land use types were recorded in the five sampling plots (Table 1).

Table 1. Geo-attributes, land-use and vehicular pollution gradient recorded in Stereocaulon foliolosum Nyl. in the five study sites of Munsyari, Pithoragarh, Uttarakhand, western Himalaya.

\begin{tabular}{|c|c|c|c|c|c|}
\hline $\begin{array}{l}\text { Site } \\
\text { abbreviation }\end{array}$ & $\begin{array}{l}\text { Elevation } \\
\text { (m) }\end{array}$ & Geo-coordinate & Land use & $\begin{array}{r}\text { Lichen } \\
\text { diversity }\end{array}$ & $\begin{array}{l}\text { Vehicular } \\
\text { frequency }\end{array}$ \\
\hline M1 & 2350 & $\begin{array}{l}\text { N } 30^{\circ} 04^{\prime} 28.27^{\prime \prime} \\
\text { E } 80^{\circ} 13^{\prime} 48.62^{\prime \prime}\end{array}$ & $\begin{array}{l}\text { Open canopy old } \\
\text { grown forest }\end{array}$ & 66.67 & 0 \\
\hline M2 & 2255 & $\begin{array}{l}\text { N } 30^{\circ} 03^{\prime} 56.86^{\prime \prime} \\
\text { E } 80^{\circ} 14^{\prime} 06.99^{\prime \prime}\end{array}$ & $\begin{array}{l}\text { Roadside } \\
\text { scrublands }\end{array}$ & 20 & 15 \\
\hline M3 & 2240 & $\begin{array}{l}\text { N } 30^{\circ} 03^{\prime} 46.27^{\prime \prime} \\
\text { E } 80^{\circ} 14^{\prime} 16.99^{\prime \prime}\end{array}$ & $\begin{array}{l}\text { Roadside } \\
\text { scrublands }\end{array}$ & 13.33 & 18 \\
\hline M4 & 1989 & $\begin{array}{l}\text { N } 30^{\circ} 04^{\prime} 25.15^{\prime \prime} \\
\text { E } 80^{\circ} 14^{\prime} 37.72^{\prime \prime}\end{array}$ & $\begin{array}{l}\text { Terraced } \\
\text { agricultural field }\end{array}$ & 33.33 & 8 \\
\hline M5 & 2128 & $\begin{array}{l}\text { N } 30^{\circ} 04^{\prime} 00.93^{\prime \prime} \\
\text { E } 80^{\circ} 14^{\prime} 30.15^{\prime \prime}\end{array}$ & $\begin{array}{l}\text { Secondary rural } \\
\text { scrublands }\end{array}$ & 26.67 & 4 \\
\hline
\end{tabular}

After curating representative lichen samples for taxonomic authentication, about 8 grams of lichen sample was pooled in from each plot and was transported to the laboratory in zip-locked airtight polyvinyl bags, for heavy metal analysis. The geotagging and elevation data recording of sampling sites were done with a hand-held GPS unit (Garmin GPSMAP ${ }^{\circledR} 76 \mathrm{~S}^{\mathrm{TM}}$ ). The vehicular density at sites was recorded as vehicle frequency/ hour (Glenn et al. 1995, Liu et al. 2017).

\section{Lichen sample authentication}

The lichen samples were authenticated up to the species level at the Lichenology Laboratory of the National Botanical Research Institute (NBRI), Lucknow, Uttar Pradesh, India using standard morpho-anatomical examination, chemical spot tests, standardized thin-layer chromatography and relevant literature (Awasthi 2007, Orange et al. 2010, Elix 2014). The authenticated samples were deposited as voucher specimens in the lichen herbarium (LWG), NBRI.

\section{Heavy metal estimation}

The metal content of lichen samples was analyzed by inductively coupled plasma- optical emission spectrometer (ICP-OES), employing Nitric $\left(\mathrm{HNO}_{3}\right)$-Perchloric $\left(\mathrm{HClO}_{4}\right)$ acid digestion method for the sample preparation (Walting 1981). Lichen samples were processed in triplicate for metal estimation.

One gram of air-dried lichen sample was ground to a fine powder using a glass mortar and pestle. The powdered lichen thallus was digested in $100 \mathrm{ml}$ glass beaker with concentrated $\mathrm{HNO}_{3}(20 \mathrm{ml})$ overnight. It was then mixed with $10 \mathrm{ml}$ of conc. $\mathrm{HNO}_{3}$ and $\mathrm{HClO}_{4}$ (4:1) solution, followed by evaporation of the acid mixture using a hot plate $\left(120^{\circ} \mathrm{C}\right)$ to complete dryness (Walting 1981). The residue was treated with $10 \mathrm{ml}$ of $20 \% \mathrm{HNO}_{3}$ for 6 hours, filtered through a Millipore filtration unit and made up to $20 \mathrm{ml}$ using Milli-Q water for analysis in ICP-OES.

The seven heavy metals- Magnesium (Mg), Zinc ( $\mathrm{Zn})$, Copper (Cu), Lead (Pb), Manganese (Mn), Nickel (Ni) and Cadmium (Cd) were analysed in digested lichen samples using inductively coupled plasma- optical emission spectrometer (ICP-OES) (PerkinElmer ${ }^{\circledR}$ Optima 2100 DV $^{\mathrm{TM}}$, Software-Winlab $32^{\mathrm{TM}}$ ). The precision and accuracy of the analytical procedure was calibrated using commercially available standards (Merck KGCA, 64271 Damstadt, Germany, ICP-Multielement standard solution IV). The heavy metal readings were reported as microgram per gram dry weight $\left(\mu \mathrm{g} \mathrm{g}^{-1} \mathrm{DW}\right)$.

\section{Data analysis}

The diversity of Stereocaulon foliolosum was estimated as \% quadrat frequency in each plot (Curtis \& 
McIntosh 1950, Rai et al. 2012b). Univariate descriptive statistics (mean and standard deviation) was used to characterize heavy metal concentrations (differential as well as total metal load- $\Sigma \mathrm{M}_{7}$ ) in Stereocaulon foliolosum collected in the five plots of Khaliya bugyal-Munsyari landscape. The heavy metal concentration in the lichens thallus at different sites were visualized using a two-dimensional metal distribution contour map using SURFER version 11.0.62 (Fig. 2). Bivariate two-tailed correlation analysis was done (Pearson's correlation coefficients) to compare explanatory variables- differential as well, total heavy metal load, vehicular density, elevation and response variable-lichen diversity using IBM $^{\circledR}$ SPSS $^{\circledR}$ Statistics ver. 20 (Rai et al. 2012b, Gupta et al. 2017).
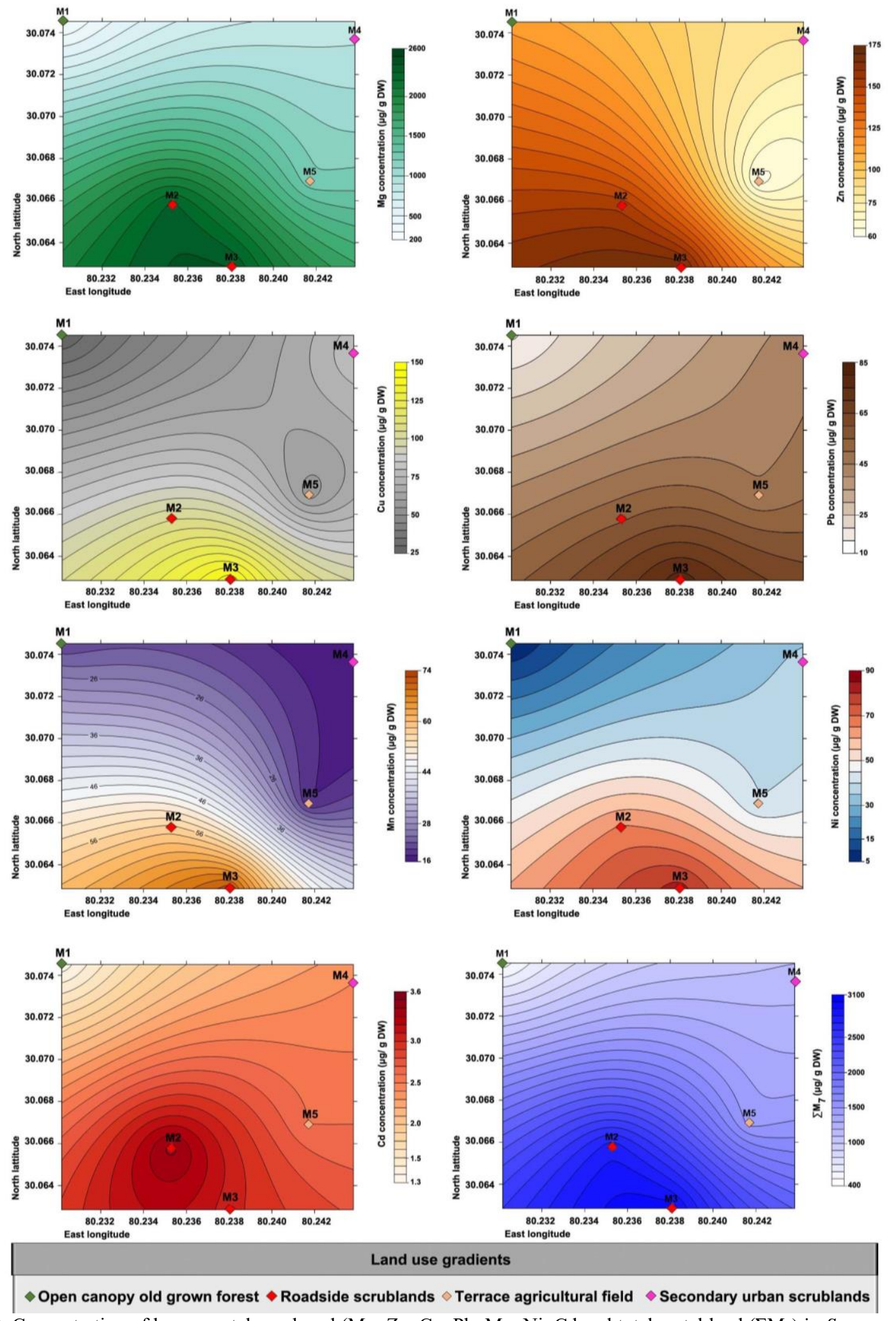

Land use gradients

ands $\diamond$ Terrace agricultural field $\diamond$ Secondary urban scrublands

Figure 2. Concentration of heavy metals analyzed $\left(\mathrm{Mg}, \mathrm{Zn}, \mathrm{Cu}, \mathrm{Pb}, \mathrm{Mn}, \mathrm{Ni}, \mathrm{Cd}\right.$ and total metal load $\left(\Sigma \mathrm{M}_{7}\right)$ in Stereocaulon foliolosum $\mathrm{Nyl}$. from different plots along four land use gradient. 
RESULTS

The diversity of Stereocaulon foliolosum was found varying in different sites. The diversity was maximum at site M1 in Khaliya bugyal which decreased to its lowest in sites M2, M3 and further increased in sites M4, M5 (Table 2). Though there was no significant linear relationship between lichen diversity and sampling plot elevation with vehicular density, polynomial fits the data suggesting that the diversity of Stereocaulon foliolosum decreases at mid-altitude (2240-2255 m) due to increased vehicular density (Table 1; Fig. 3). Further as the land-use intensity decrease at lower elevation the lichen diversity increases in accordance with decreased vehicular density (Table 1; Fig. 3).

Table 2. Pearson's correlation coefficients between quadrat frequency, vehicular density, elevation and heavy metal accumulation in Stereocaulon foliolosum Nyl. from Munsyari, Pithoragarh district, Uttarakhand state, India, Western Himalaya (significant correlations are tagged)

\begin{tabular}{|c|c|c|c|c|c|c|c|c|}
\hline & VD & $\boldsymbol{\Sigma} \mathbf{M}_{7}$ & Mg & Zn & $\mathbf{C u}$ & $\mathbf{P b}$ & Mn & $\mathbf{N i}$ \\
\hline$\Sigma \mathbf{M}_{7}$ & $0.954^{\mathrm{a}}$ & & & & & & & \\
\hline Mg & $0.941^{\mathrm{a}}$ & $0.999^{\mathrm{b}}$ & & & & & & \\
\hline $\mathrm{Zn}$ & 0.768 & 0.729 & 0.702 & & & & & \\
\hline $\mathrm{Cu}$ & $0.982^{b}$ & $0.925^{\mathrm{a}}$ & $0.909^{\mathrm{a}}$ & & & & & \\
\hline $\mathbf{P b}$ & $0.914^{\mathrm{a}}$ & $0.908^{\mathrm{a}}$ & $0.901^{\mathrm{a}}$ & & & & & \\
\hline Mn & $0.905^{\mathrm{a}}$ & $0.914^{\mathrm{a}}$ & $0.896^{\mathrm{a}}$ & $0.927^{\mathrm{a}}$ & & & & \\
\hline $\mathbf{N i}$ & $0.961^{b}$ & $0.977^{\mathrm{b}}$ & $0.973^{b}$ & 0.641 & $0.967^{\mathrm{b}}$ & $0.975^{\mathrm{b}}$ & 0.867 & \\
\hline Cd & 0.863 & $0.920^{\mathrm{a}}$ & $0.934^{\mathrm{a}}$ & 0.455 & 0.822 & 0.847 & 0.688 & $0.914^{\mathrm{a}}$ \\
\hline
\end{tabular}

Note: VD- Vehicular density at sites, Mg- Magnesium concentration in the thallus, Zn- Zinc concentration in the thallus, $\mathrm{Cu}$ Copper concentration in the thallus, $\mathrm{Pb}$ - Lead concentration in the thallus, Mn- Manganese concentration in the thallus, NiNickel concentration in the thallus, Cd- Nickel concentration in the thallus, $\Sigma \mathrm{M}_{7^{-}}$Total accumulation of the seven heavy metals analysed.

${ }^{\mathrm{a}}$ Correlation is significant at the 0.05 level (2-tailed), ${ }^{\mathrm{b}}$ Correlation is significant at the 0.01 level (2-tailed).
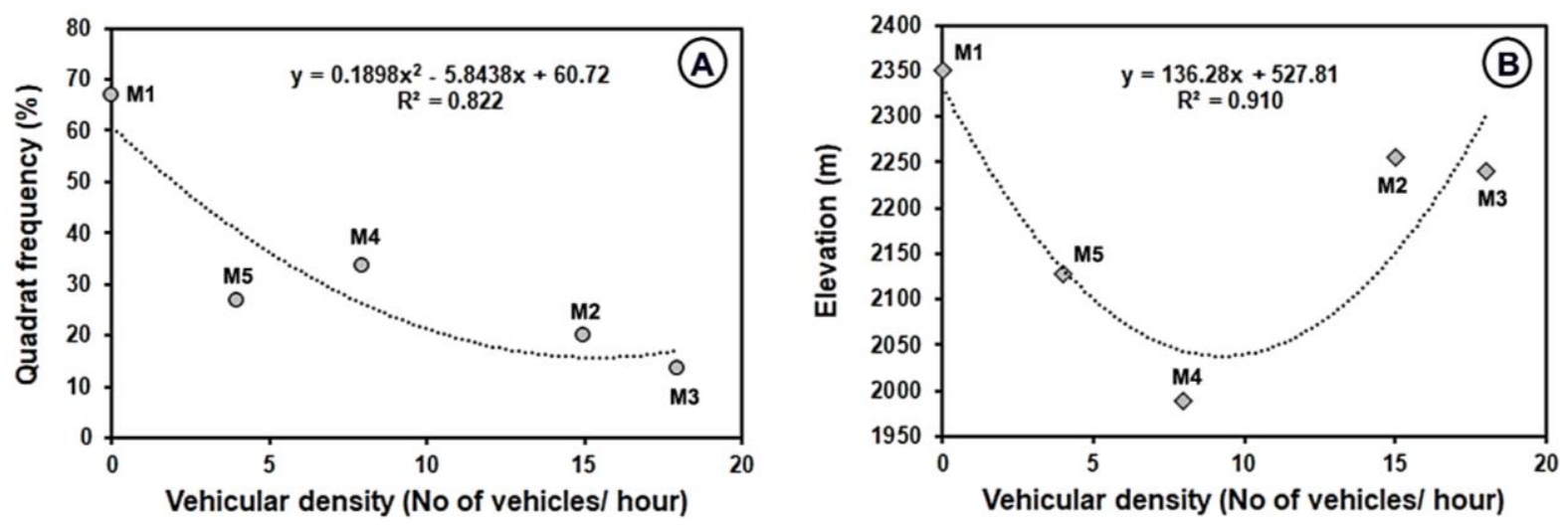

Figure 3. Diversity and elevation of Stereocaulon foliolosum Nyl. plotted against vehicular density: A. Diversity (\% quadrat frequency); B, Elevation of sampling plot elevation of all sites. [The dashed line is a best-fit trend polynomial; See table 1 for abbreviations]

The bivariate two-tailed correlation analysis concludes that the vehicular density was positively correlated with total metal load $\left(\mathrm{\Sigma M}_{7}\right)$ and ambient air deposition of metals ( $\mathrm{Mg}, \mathrm{Cu}, \mathrm{Pb}, \mathrm{Mn}$, and $\mathrm{Ni}$ ) (Table 2). Among the seven heavy metal analyzed significant positive correlation was found different metals i.e. $\mathrm{Mg}-\mathrm{Cu}-\mathrm{Pb}-\mathrm{Mn}$ $\mathrm{Ni}-\mathrm{Cd}, \mathrm{Zn}-\mathrm{Mn}, \mathrm{Cu}-\mathrm{Ni}$, Pb-Ni, Ni-Cd suggesting a synergistic accumulation of heavy metals in Stereocaulon foliolosum thallus at the five sites (Table 2).

\section{DISCUSSION AND CONCLUSION}

The lichen communities in Himalaya are highly sensitive to zoo-anthropogenic pressures (Rai et al. 2012a, b). The higher lichen diversity of Stereocaulon foliolosum at high elevation plots with least vehicular density and the further decrease of diversity along decreasing elevational gradient can be attributed to increased vehicular density in the study landscape of Munsyari (Mendil et al. 2009, Gupta et al. 2017). The positive significant correlation of vehicular density at plots and the thallus heavy metal concentration (Table 2) in Stereocaulon foliolosum indicate that vehicular movement is a major source of pollution in and around Munsyari township (Gupta et al. 2017, Liu et al. 2017). The synergistic accumulation of heavy metals in Stereocaulon foliolosum observed between different estimated metals can be attributed to their higher deposition through vehicular exhaust (Ng et al. 2006, Liu et al. 2017). 
The perpetual distribution of Stereocaulon foliolosum throughout the study landscape and correlative accumulation of heavy metals along different land use validates the bioindicator capabilities of Stereocaulon foliolosum in the temperate habitats of Himalaya. The study further highlights that lichens having such larger distribution can be used for long-term biomonitoring studies in the Himalayan habitats.

\section{ACKNOWLEDGEMENTS}

Authors are grateful to Director, National Botanical Research Institute, Lucknow; Principal and H.O.D Botany department, Pt. L.M.S. Government Post Graduate College, Rishikesh (Dehradun)-249201, Uttarakhand, India, for providing necessary laboratory facilities.

\section{REFERENCES}

Awasthi DD (2007) A compendium of the Macrolichens from India, Nepal and Sri Lanka. Bishen Singh Mahendra Pal Singh, Dehra Dun.

Bergamaschi L, Rizzio E, Valcuvia MG, Verza G, Profumo A \& Gallorini M (2002) Determination of trace elements and evaluation of their enrichment factors in Himalayan lichens. Environmental Pollution 120: 137-144.

Curtis JT \& McIntosh RP (1950) The Interrelations of Certain Analytic and Synthetic Phytosociological Characters. Ecology 31: 434-455.

Elix JA (2014) A Catalogue of Standardized Chromatographic Data and Biosynthetic Relationships for Lichen Substances, Third edition. Published by the author, Canberra. Available from: https://www.anbg.gov.au/abrs/lichenlist/Chem\%20Cat\%203.pdf (accessed: 5 March 2019)

Galloway DJ (1992) Biodiversity: a lichenological perspective. Biodiversity and Conservation 1: 312-323.

Gasparyan A, Sipman HL, Marini L \& Nascimbene J (2018) The inclusion of overlooked lichen microhabitats in standardized forest biodiversity monitoring. The Lichenologist 50:231-237.

Giordani P, Brunialti G, Bacaro G \& Nascimbene J (2012) Functional traits of epiphytic lichens as potential indicators of environmental conditions in forest ecosystems. Ecological Indicators 18: 413-420.

Glenn MG, Gomez-Bolea A \& Lobello R (1995) Metal Content and Community Structure of Cryptogam Bioindicators in relation to Vehicular Traffic in Montseny Biosphere Reserve (Catalonia, Spain). The Lichenologist 27: 291-304.

Greig-Smith P (1983) Quantitative Plant Ecology, $3^{\text {rd }}$ edition. Blackwell, London.

Gupta S, Bajpai O, Rai H, Upreti DK, Sharma PK \& Gupta RK (2018) Untangling Quantitative Lichen Diversity in and Around Badrinath Holy Pilgrimage of Western Himalaya, India. Journal of Graphic Era University 6(1): 36-46.

Gupta S, Khare R, Bajpai O, Rai H, Upreti DK, Gupta RK \& Sharma PK (2016) Lichen as Bioindicator for Monitoring Environmental Status in Western Himalaya, India. International Journal of Environment 5(2): $1-15$.

Gupta S, Rai H, Upreti DK, Gupta RK \& Sharma PK (2017) Lichenised fungi Phaeophyscia (Physciaceae, Ascomycota) as indicator of ambient air heavy metal deposition, along land use gradient in an alpine habitat of western Himalaya, India. Pollution Research 36: 150-157.

Holt EA, McCune B \& Neitlich P (2007) Succession and community gradients of arctic macrolichens and their relation to substrate, topography, and rockiness. Pacific Northwest Fungi 2: 1-21.

Honegger R (1991) Functional aspects of the lichen symbiosis. Annual Review of Plant Biology 42: 553-578.

KakaÏ RG, Sinsin B \& Palm R (2008) Etude dendrométrique de Pterocarpus erinaceus Poir. des formations naturelles de la zone soudanienne au Bénin. Agronomie africaine 20: 233-255.

Krebs CJ (1989) Sampling designs-random sampling. In: Krebs CJ (ed) Ecological Methodology. Harper and Row, New York, pp. 200-236.

Kumar J, Rai H, Khare R, Upreti DK, Dhar P, Tayade AB, Chaurasia OP \& Srivastava RB (2014) Elevational controls of lichen communities in Zanskar valley, Ladakh, a Trans Himalayan cold desert. Tropical Plant Research 1(2): 48-54.

Liu HJ, Wang JG, Xia Y, Yang MJ, Liu SW, Zhao LC, Guo XP, Jiang YJ, Li X, Wu QF \& Fang SB (2017) Elemental compositions of lichens from Duolun County, Inner Mongolia, China: Origin, road effect and species difference. Scientific Reports 7: 5598.

Loppi S, Frati L, Paoli L, Bigagli V, Rossetti C, Bruscoli C \& Corsini A (2004) Biodiversity of epiphytic lichens and heavy metal contents of Flavoparmelia caperata thalli as indicators of temporal variations of air pollution in the town of Montecatini Terme (central Italy). Science of the total environment 326: 113-122.

www.tropicalplantresearch.com 
Mendil D, Çelik F, Tuzen M \& M Soylak (2009) Assessment of trace metal levels in some moss and lichen samples collected from near the motorway in Turkey. Journal of hazardous materials 166: 1344-1350.

$\mathrm{Ng} \mathrm{OH}$, Tan BC \& Obbard JP (2006) Lichens as bioindicators of atmospheric heavy metal pollution in Singapore. Environmental Monitoring and Assessment 123: 63-74.

Orange A, James PW \& White FJ (2001) Microchemical Methods for the Identification of Lichens. British Lichen Society.

Pinho P, Bergamini A, Carvalho P, Branquinho C, Stofer S, Scheidegger C \& Maguas C (2012) Lichen functional groups as ecological indicators of the effects of land-use in Mediterranean ecosystems. Ecological indicators 15: 36-42.

Purvis OW (2000) Biomonitoring. In: Purvis OW (ed) Lichens. Natural History Museum, London, pp. 76-85.

Rai H, Khare R, Gupta RK \& Upreti DK (2012a) Terricolous lichens as indicator of anthropogenic disturbances in a high altitude grassland in Garhwal (Western Himalaya), India. Botanica Orientalis 8: 16-23.

Rai H, Upreti DK \& Gupta RK (2012b) Diversity and distribution of terricolous lichens as indicator of habitat heterogeneity and grazing induced trampling in a temperate-alpine shrub and meadow. Biodiversity and Conservation 21: 97-113.

Rao KS \& Pant R (2001) Land use dynamics and landscape change pattern in a typical micro watershed in the mid elevation zone of central Himalaya, India. Agriculture, Ecosystems and Environment 86: 113-124.

Scheidegger C, Groner U, Keller C \& Stoffer S (2002) Biodiversity assessment tools lichens. In: Nimis PL, Scheidegger C \& Wolseley PA (eds) Monitoringwith lichens-monitoring lichens. [NATO Science Series IV, Earth and Environmental Science, vol. 7]. Kluwer Academic Publishers, Dordrecht, pp. 359-365.

Singh JS \& Singh SP (1987) Forest vegetation of the Himalaya. The Botanical Review 53: 80-192.

Spribille T, Tuovinen V, Resl P, Vanderpool D, Wolinski H, Aime MC, Kevin S, Edith S, Merje T-H, Göran T, Helmut M, Hanna J \& McCutcheon JP (2016) Basidiomycete yeasts in the cortex of ascomycete macrolichens. Science 353: 488-492.

Tiwari P (2008) Land use changes in Himalaya and their impacts on environment, society and economy: A study of the lake region in Kumaon Himalaya, India. Advances in Atmospheric Sciences 25: 1029-1042.

Walting RJ (1981) A manual of methods for use in the southern African marine pollution monitoring programme. In: South African Natural Scientific Programmes, Report 44. pp. 81.

Yadav S, Kumar A, Raj H \& Bora HR (2018) Lichen diversity in coal mining affected areas of Makum coalfield, Magherita, Assam. Tropical Plant Research 5(2): 243-249. 